\title{
Pelatihan Foto Makanan Dengan Menggunakan Kamera Handphone Untuk Komite Sekolah TK Tunas Muda I IKKT
}

\author{
Erlina Novianti*, Silviana Amanda Aurelia Tahalea, Malcheni \\ Fakultas Seni Rupa dan Desain, Universitas Trisakti \\ *Email: erlina@trisakti.ac.id
}

\author{
Received: 26 April 2021; Revised: 16 July 2021; Accepted: 13 August 2021 \\ DOI: http://dx.doi.org/10.37905/aksara.7.3.967-976.2021
}

\begin{abstract}
Abstrak
Komite Sekolah TK Tunas Muda I IKKT merupakan Komite Sekolah yang aktif menyelenggarakan dan mengikuti kegiatan yang positif. Berdasarkan survei yang dilakukan, sebagian besar anggota Komite Sekolah mempunyai usaha kuliner yang memutuhkan media foto sebagai promosi. Oleh karena itu tim Pengabdian kepada Masyarakat FSRD Universitas Trisakti ikut berperan serta dengan memberikan pelatihan membuat foto makananan dengan menggunakan kamera handphone. Pelaksanaan pelatihan dilakukan dengan menggunakan metode demonstrasi oleh instruktur. Setelah peserta PkM mendapatkan materi pelatihan, peserta PkM akan mempraktikkan secara langsung yang didampingi oleh tim PkM. Pelaksanaan pelatihan ini dilakukan secara online, dikarenakan kondisi Jakarta masih dalam situasi pandemi Covid-19. Hasil dari pelatihan ini yaitu berupa foto makanan yang menarik, yang dapat digunakan sebagai media promosi usaha kuliner yang dimiliki oleh peserta PkM. Selain itu pelatihan ini dapat menambah pengetahuan mengenai fotografi, menambah kreativitas dalam memilih properti yang digunakan dalam pemotretan serta dapat menata makanan sehingga tampilan foto terlihat sangat menarik.
\end{abstract}

Kata Kunci

Foto Menggunakan Kamera Handphone, Foto Makanan, Komite Sekolah, Pelatihan

\section{Pendahuluan}

Komite Sekolah merupakan lembaga mandiri yang beranggotakan orangtua atau wali murid, komunitas sekolah dan tokoh masyarakat yang peduli tentang pendidikan. Keberadaan Komite Sekolah sesuai dengan Permendikbud Nomor 75 Tahun 2016 tentang Komite Sekolah. Komite Sekolah bertujuan untuk mewadahi dan melaksanakan aspirasi dan prakarsa masyarakat dalam menghasilkan kebijakan operasional dan program pendidikan di satuan pendidikan dan meningkatkan tanggung jawab dan peran serta masyarakat dalam penyelenggaraan di satuan pendidikan. Salah satu lembaga Komite Sekolah yang aktif adalah Komite Sekolah TK Tunas Muda I IKKT yang berlokasi di Jl. Jalak No.1, RT.8/RW.2 Palmerah, Kota Jakarta Barat. Banyak kegiatankegiatan yang dilakukan oleh Komite Sekolah TK Tunas Muda I IKKT diantaranya adalah rutin menyelenggarakan atau mengikuti pelatihan-pelatihan yang dapat meningkatkan pengetahuan, ketrampilan dan kreatifitas seluruh anggota. Keseluruhan anggota Komite Sekolah TK Tunas Muda I IKKT adalah para ibu dari orangtua murid yang sangat aktif dan mempunyai hobby yang sama yaitu memasak. Berawal dari hobby memasak yang terus dikembangkan akhirnya beberapa anggota Komite Sekolah ini menjadikan hobbynya tersebut menjadi usaha kuliner yang menghasilkan. Hal tersebut di dorong dengan adanya situasi pandemi Covid-19 yang masih dialami hampir seluruh 
penduduk dunia yang mengharuskan untuk membatasi kegiatan di luar rumah. Kondisi ini dimanfaatkan oleh anggota Komite Sekolah untuk lebih menekuni hobby memasak, yang akhirnya menghasilkan menu-menu baru yang dijadikan sebagai usaha kuliner.

Usaha kuliner yang dihasilkan oleh Komite Sekolah TK Tunas Muda I IKKT ini dapat berkembang dengan baik apabila ada media promosi yang menarik. Salah satu media promosi yang menarik, efektif dan mudah di buat adalah dengan menggunakan media foto. Penggunaan media foto produk makanan akan terlihat lebih nyata, menggugah selera dan dapat menarik minat pembeli. Memotret produk makanan saat sekarang ini tidak harus dengan menggunakan kamera profesional. Memotret produk makanan untuk pemula akan lebih mudah dan praktis dengan menggunakan kamera handphone, karena kamera handphone saat sekarang ini banyak memiliki fitur-fitur yang mumpuni dan dapat meghasilkan kualitas foto yang baik. Kebutuhan anggota Komite Sekolah untuk menghasilkan foto makanan dengan menggunakan kamera handphone sebagai media promosi usaha kuliner yang dimiliki ini disambut baik oleh tim Pengabdian Kepada Masyarakat Fakultas Seni Rupa dan Desain (FSRD) Universitas Trisakti untuk menyelenggarakan pelatihan foto makanan dengan menggunakan handphone untuk Komite TK Tunas Muda I IKKT.

Penyelenggaraan kegiatan pelatihan ini merupakan salah satu solusi dan dukungan dari civitas akademika Fakultas Seni Rupa dan Desain Universitas Trisakti terhadap potensi yang dimiliki oleh anggota Komite Sekolah TK Tunas Muda I IKKT. Adapun tujuan dari pelatihan ini adalah untuk meningkatkan pengetahuan, ketrampilan dan kreatifitas dalam bidang fotografi, selain itu untuk dapat membantu anggota Komite Sekolah untuk dapat menghasilkan produk foto makanan yang dapat dijadikan sebagai media promosi usaha kuliner yang dimiliki.

Tim PkM Fakultas Seni Rupa dan Desain Universitas Trisakti yang berlatar belakang keilmuan seni rupa dan desain, tidak hanya memberikan pengetahuan dalam bidang fotografi saja, tetapi memberikan pengetahuan mengenai seni secara garis besar serta memberikan pengetahuan mengenai pemilihan properti yang sesuai dengan makanan yang dipilih dan menata makanan sehingga dapat mendukung dalam menciptakan foto produk makanan yang tidak hanya sekedar baik, tetapi dapat menghasilkan foto produk makan yang menarik, terlihat nyata dan menarik minat pembeli. Dengan adanya pelatihan ini dapat memberikan manfaat untuk anggota Komite Sekolah yaitu dapat menghasilkan foto produk makanan secara mandiri yang dapat mendukung hobby dan usaha kuliner yang dimiliki.

\section{Metode}

Tahap pertama yang dilakukan adalah koordinator PkM melakukan survei terlebih dahulu dengan ketua Komite Sekolah TK Tunas Muda I IKKT Jakarta Barat. Berdasarkan hasil survei diketahui bahwa banyak anggota Komite Sekolah yang menekuni hobby memasak, terlebih lagi dalam kondisi pandemi seperti ini yang bermula dari hobby memasak tetapi karena ditekuni berkembanglah menjadi usaha kuliner. Kebetuhunan dalam membuat promosi produk makanan dengan menggunakan foto sangat dibutuhkan oleh anggota komite sekolah dalam usaha kulinernya. Hal tersebut disampaikan oleh ketua Komite Sekolah kepada Koordinator PkM. Dari survei dan pembicaraan tersebut yang mendasari diselenggarakannya pelatihan foto makanan menggunakan kamera handphone untuk Komite Sekolah TK Tunas Muda I IKKT. 
Tahap selanjutnya yaitu Koordinator PkM melakukan diskusi dengan Ketua Komite Sekolah TK Tunas Muda I IKKT mengenai lokasi, waktu dan sistem pelatihan, yang akhirnya disepakati bersama bahwa pelatihan dilakukan pada tanggal 13 Februari 2021 pukul 10.00 WIB dengan sistem pelaksanaan pelatihan secara online melalui media zoom. Pelaksanaan pelatihan disepakati secara online dikarenakan mengingat kondisi saat sekarang ini khususnya di daerah Jakarta yang masih terdampak pandemi Covid-19. Tim PkM mengatur pelaksanaan pelatihan sebaik mungkin tanpa mengurangi isi materi dari pelatihan walupun pelatihan ini diselenggarakan secara online. Penguasaan teknologi zoom juga sudah dikuasai oleh peseta PkM sehingga dapat memudahkan terselenggaranya acara pelatihan.

Metode yang digunakan dalam pelaksanaan pelatihan ini adalah dengan menggunakan metode demonstrasi atau memperagakan secara langsung. Metode demonstrasi adalah metode penyajian pelajaran dengan memperagakan dan mempertunjukkan kepada siswa tentang suatu proses, situasi atau benda tertentu baik sebenernya atau hanya sekedar tiruan (Winengsih, 2017:3). Tujun digunakannya metode metode demonstrasi ini agar tim PkM dapat memperagakan secara langsung dan diharapkan materi-materi yang di peragakan dapat lebih mudah diterima oleh peserta PkM.

\section{Hasil dan Pembahasan Persiapan Pelatihan}

Komite Sekolah TK Tunas Muda I IKKT berlokasi di Jl. Jalak No.1, RT.8/RW.2 Palmerah, Kota Jakarta Barat. Anggota Komite Sekolah ini terdiri dari perwakilan orang tua murid dari kelas bermain, TK A dan TK B. Komite Sekolah TK Tunas Muda I IKKT termasuk salah satu komite sekolah yang aktif mengadakan kegiatan rutin diantaranya adalah menyelenggarakan seminar tentang kesehatan, pelatihan tata rias wajah dan pelatihan-pelatihan lainnya. Kegiatan-kegiatan yang diselenggarakan oleh Komite Sekolah selalu di adakan di dalam lokasi Komite sekolah tepatnya berada di dalam komplek Hankam Slipi, Jakarta Barat.

Berikut adalah lokasi dari Komite Sekolah TK Tunas Muda I IKKT:

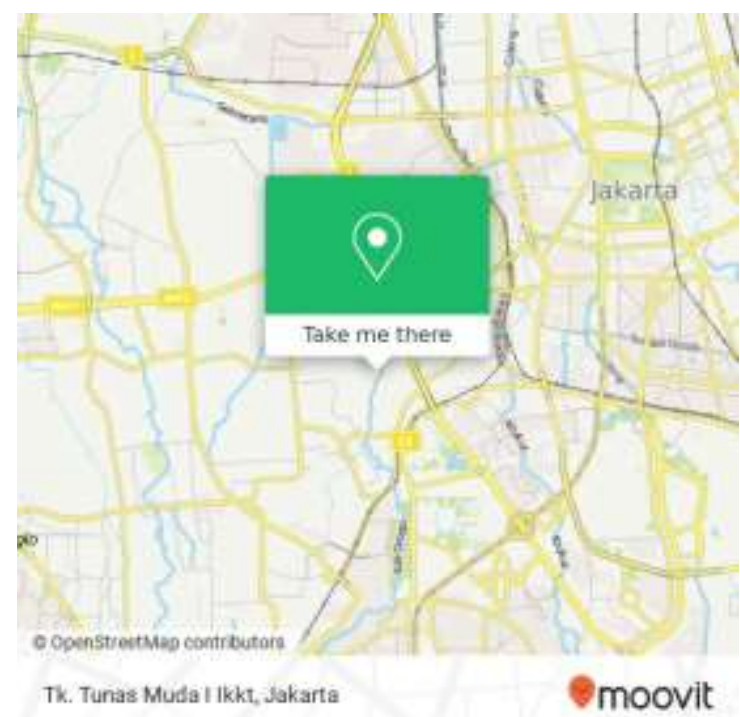

Gambar 1: Peta Wilayah Komite Sekolah TK Tunas Muda I IKKT 

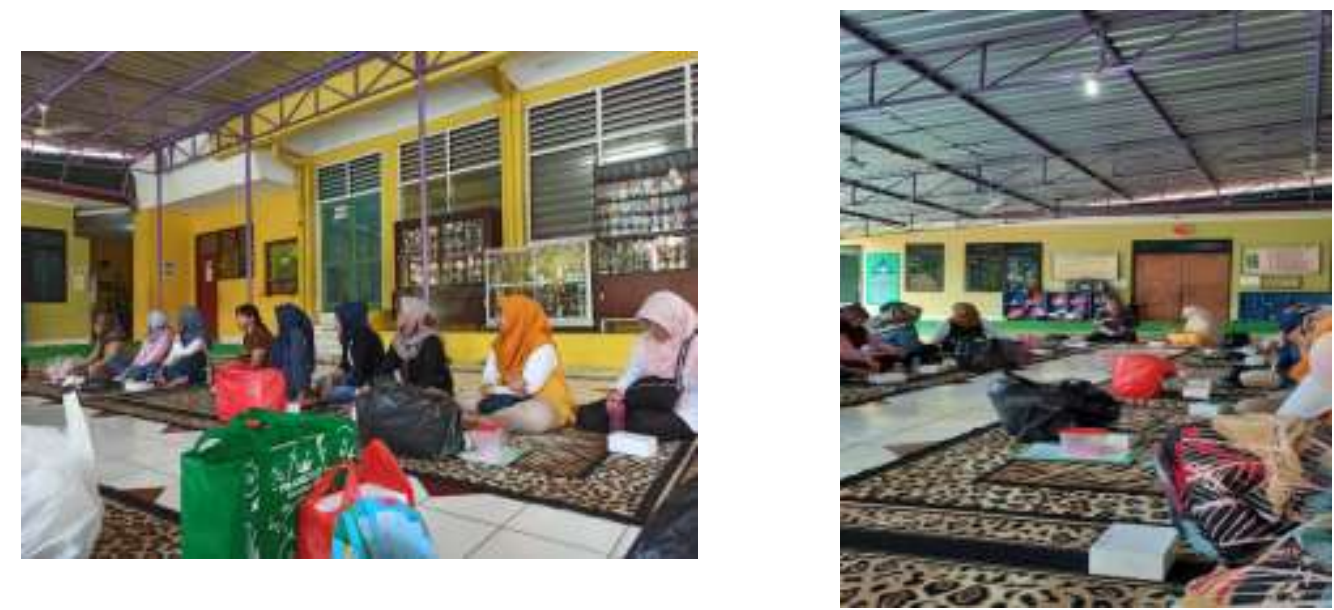

Gambar 2: Kegiatan Rutin yang diselenggarakan oleh Komite Sekolah TK Tunas Muda I IKKT

Pada persiapan awal koordinator PkM membuat materi yang akan disampaikan. Materi di persiapkan dengan jelas, menarik dan sederhana dengan harapan materi yang di sampaikan dapat mudah di mengerti oleh peserta PkM. Materi pelatihan akan disiapkan menjadi 2 kategori yaitu penjelasan materi mengenai dasar-dasar foto makanan beserta contohnya dan materi demo foto makanan. Koordinator PkM membuat foto produk makanan yang digunakan sebagai contoh foto untuk pelatihan. Pembuatan contoh foto produk makanan ini menggunakan jenis kue yang mudah didapatkan dan mempunyai warna yang beragam sehingga tampilan foto terlihat segar dan dapat menggugah selera. Properti foto yang digunakan adalah bahan-bahan yang mudah didapat sehingga memudahkan peserta $\mathrm{PkM}$ agar peserta $\mathrm{PkM}$ dapat mempraktekkan secara mandiri dan dapat mengkreasikan sendiri sesuai dengan kebutuhan. Koordinator PkM juga mempersiapkan materi, perlengkapan dan properti untuk demonstrasi. Demontrasi akan dilakukan secara langsung dengan sistem online. Pemilihan makanan yang digunakan pada saat demontrasi yaitu jenis makanan utama. Fotografi makanan adalah foto yang menampilkan objek foto makanan dalam berbagai jenis. Food and bevereges juga termasuk kategori fotografi makanan (Gunawan, 2014:1242). Pada pelaksanaan pelatihan ini peserta $\mathrm{PkM}$ akan mendapatkan dua kategori memotret makanan dengan jenis kue dan jenis makanan utama. Dengan demikian peserta PkM mendapatkan pengetahuan mengenai fotografi makanan yang lengkap yang nantinya dapat dijadikan sebagai media promosi usaha kuliner yang dimiliki.

\section{Pelaksanaan Pelatihan}

Pelaksanaan pelatihan memotret makanan dengan menggunakan kamera handphone dilaksanakan pada tanggal 13 Februari 2021 pukul 10.00 WIB. Pelaksanaa pelatihan diselenggarakan secara online dirumah peserta masing-masing dengan menggunakan media zoom. Keseluruhan peserta PkM sebelumnya sudah menguasai penggunaan media zoom sehingga siap mengikuti jalannya pelatihan secara online. Tim PkM pada pelatihan ini terdiri dari 1 dosen sebagai koordinator PkM, 2 dosen sebagai instruktur PkM, 1 alumni, 1 mahasiswa dan 1 tenaga pendidikan. Keseluruhan tim PkM sudah mempunyai tanggungjawab masing-masing yang sudah disepakati bersama. 

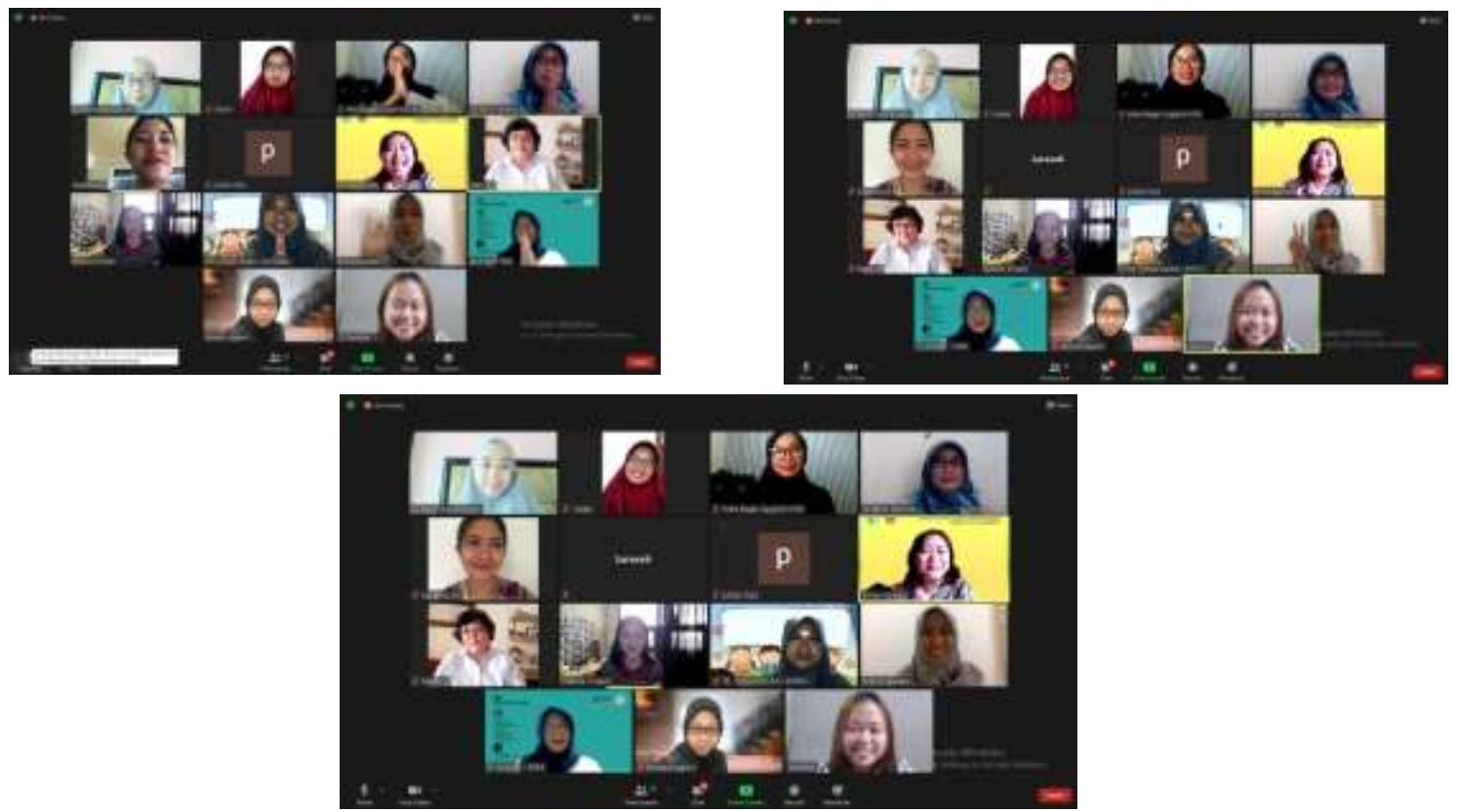

Gambar 3: Peserta PkM Pelatihan Memotret Makanan Menggunakan Kamera Handphone

Pelaksanaan kegiatan pelatihan ini diawali dengan pembukaan, sambutan dan perkenalan yang disampaikan oleh koordinator PkM. Setelah itu koordinator PkM menyampaikan materi mengenai dasar-dasar fotografi makanan, persiapan membuat foto makanan dan menjelaskan mengenai contoh-contoh foto makanan dengan jenis kue yang sudah dipersiapkan. Tim PkM mengemas semua materi, persiapan dan pelaksanaan kegiatan secara praktis karena pelaksanaan pelatihan yang diselenggarakan melalui online di tempat masing-masing. Persiapan pemotretan disesuaikan dengan kesiapan peralatan yang dapat ditemukan di tempat peserta PkM masing-masing. Sedangkan lighting dalam pemotretan menggunakan cahaya matahari dengan jenis window lighting. Instrikstrur PkM membantu dalam menjelaskan mengenai seni dalam menata makanan yang akan di foto agar terlihat menarik, selain itu instruktur PkM memberikan pengetahuan dalam memadu padankan warna yang digunakan, jenis-jenis pemilihan properti yang digunakan, komposisi serta angle dalam pemotretan foto makanan. Hal tersebut penting untuk disampaikan karena akan menjadi pendukung terciptanya foto makanan yang baik dan menarik.

Adapun materi yang disampaikan adalah sebagai berikut:

1. Pengertian tentang fotografi makanan.

2. Teknik foto dalam fotografi makanan.

3. Referensi Foto makanan yang sedang diminati.

4. Fungsi Foto makanan.

5. Contoh foto makanan yang dibuat oleh tim PkM. 

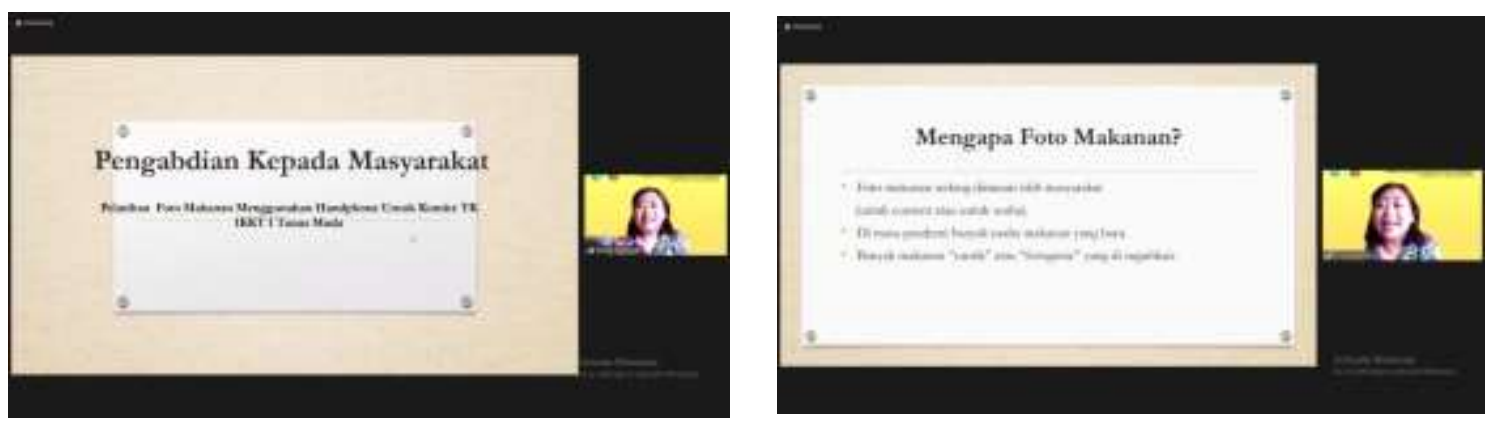

Gambar 4 : Penjelasan Materi Dasar-Dasar Fotografi Makanan
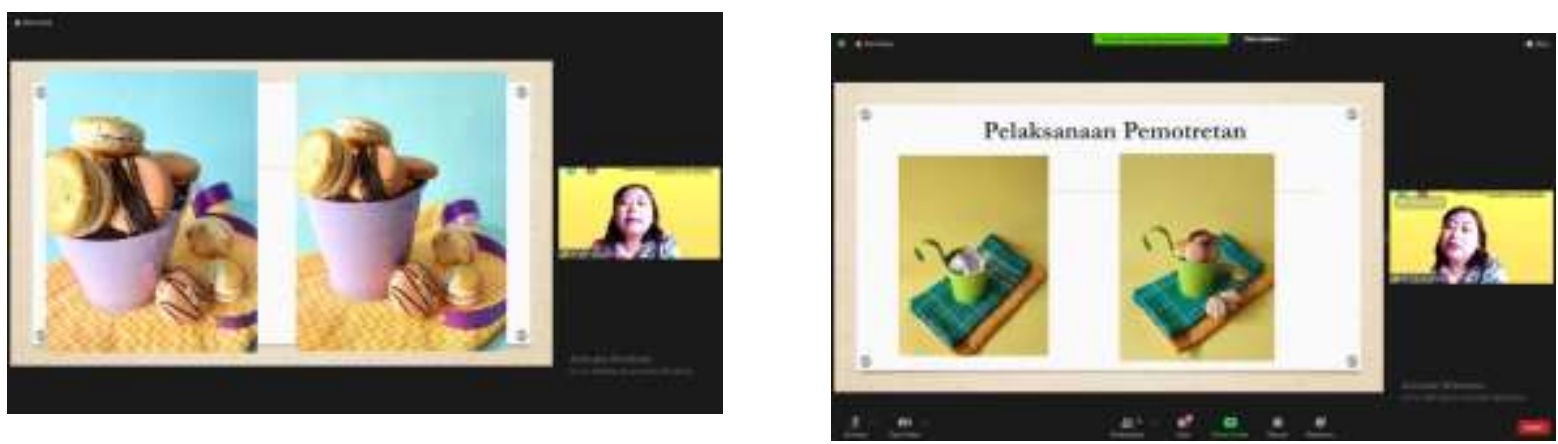

Gambar 5: Penjelasan Materi Memotret Jenis Kue

Selanjutnya tim PkM memberikan contoh atau demo secara langsung membuat foto makanan dengan jenis makanan utama. Pada pelaksanaan demo peserta PkM dapat saling bertanya dan berdiskusi dengan tim PkM mengenai hal-hal yang kurang dimengerti atau memberikan pendapat atau usul pada proses pembuatan foto makanan dengan menggunakan kamera handphone ini.

Adapun yang disampaikan dalam materi demo makanan ini adalah sebagai berikut:

1. Properti yang digunakan dalam pemotretan foto makanan.

2. Window lighting yang digunakan dalam foto makanan.

3. Penataan makanan

4. Angle dan komposisi dalam pemotretan
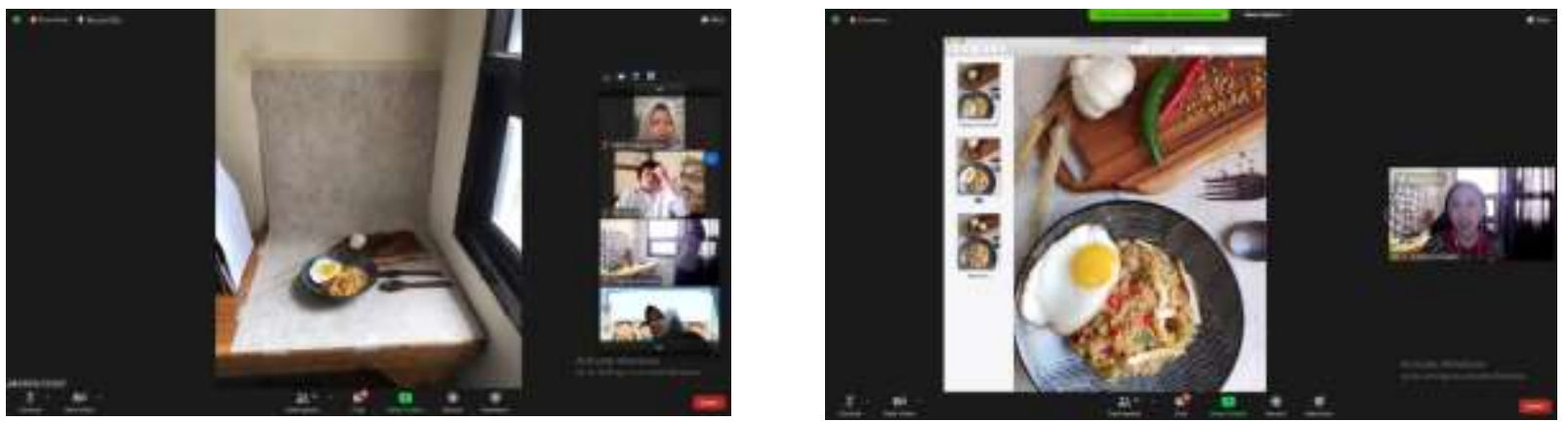

Gambar 6: Demo Foto Makanan Dengan Jenis Menu Utama 
Setelah peserta PkM mendapatkan materi dan demo yang dilakukan secara langsung, kegiatan dilakukan dengan melakukan praktik secara mandiri oleh peserta PkM di tempat masing-masing. Menu dan properti yang dipilih oleh peserta PkM sangat bervariasi, karena disesuaikan dengan kesiapan masing-masing peserta. Pemilihan tempat yang tepat juga disesuaikan masing-masing peserta PkM karena tempat yang dipilih harus memenuhi syarat pencahayaan matahari yang baik seperti di teras rumah atau di dekat jendela. Pada pelaksanaan praktek secara mandiri tim PkM juga melakukan pendampingan secara online mengarahkan dan melakukan diskusi sehingga pelaksanaan praktek dapat berjalan secara aktif.

\section{Evaluasi Pelatihan}

Pelaksanaan kegiatan pelatihan ini secara keseluruhan berjalan dengan baik dan lancar. Walaupun pelaksanaan kegiatan dilakukan secara online, tetapi antusias peserta PkM sangat tinggi. Hal tersebut terlihat dari pertanyaan-pertanyaan yang ditanyakan oleh peserta PkM yang menjadi diskusi bersama. Keingintahuan peserta mengenai pelatihan ini juga terlihat dari keseriusan peserta dalam mengikuti dan memperhatikan setiap materi yang disampaikan. Pelatihan ini terdapat sedikit kendala yaitu karena diselenggarakan secara online dan sifat dari pelatihan ini adalah demo, tim PkM harus mengalokasikan waktu lebih karena pertanyaan dan demo yang di lakukan oleh peserta PkM dilakukan secara mandiri di tempat masing-masing, tetapi hal tersebut tidak mempengaruhi capaian dari kegiatan pelatihan ini. Kendala lainnya adalah beberapa peserta ada yang belum selesai mencoba sehingga tim PkM melakukan pendampingan pelatihan untuk memberikan masukan terhadap karya yang dihasilkan di luar pelatihan. Walaupun demikian tim PkM selalu terbuka apabila ada peserta PkM yang ingin bertanya atau menghendaki pendampingan di luar waktu pelatihan.

\section{Hasil Pelatihan}

Pelaksanaan pelatihan dilaksanaan selama kurang lebih 3 jam. Dari pelatihan ini peserta PkM dapat menghasilkan karya foto makanan yang sesuai dengan kriteria foto makanan yang dapat digunakan untuk promosi. Dengan keikutsertaan anggota Komite Sekolah terhadap pelatihan ini diharapkan dapat menambah informasi, pengetahuan, kreatifitas dan dapat meghasilkan foto makanan yang berkualitas yang dapat dijadikan sebagai penunjang usaha makanan yang dimiliki oleh anggota komite sekolah. Pelatihan seperti ini dapat dijadikan sebagai tambahan pendidikan non formal untuk peserta PkM. Pendidikan non formal menurut kamus besar bahasa Indonesia adalah segenap bentuk pelatihan yang diberikan secara terorganisasi di luar pendidikan formal, misalnya kursus keterampilan.
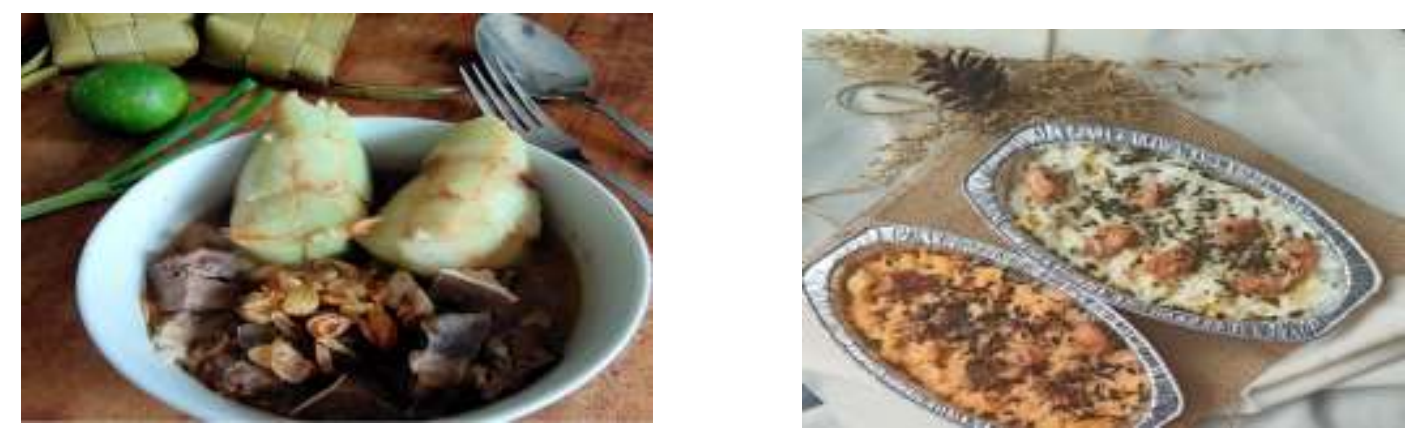

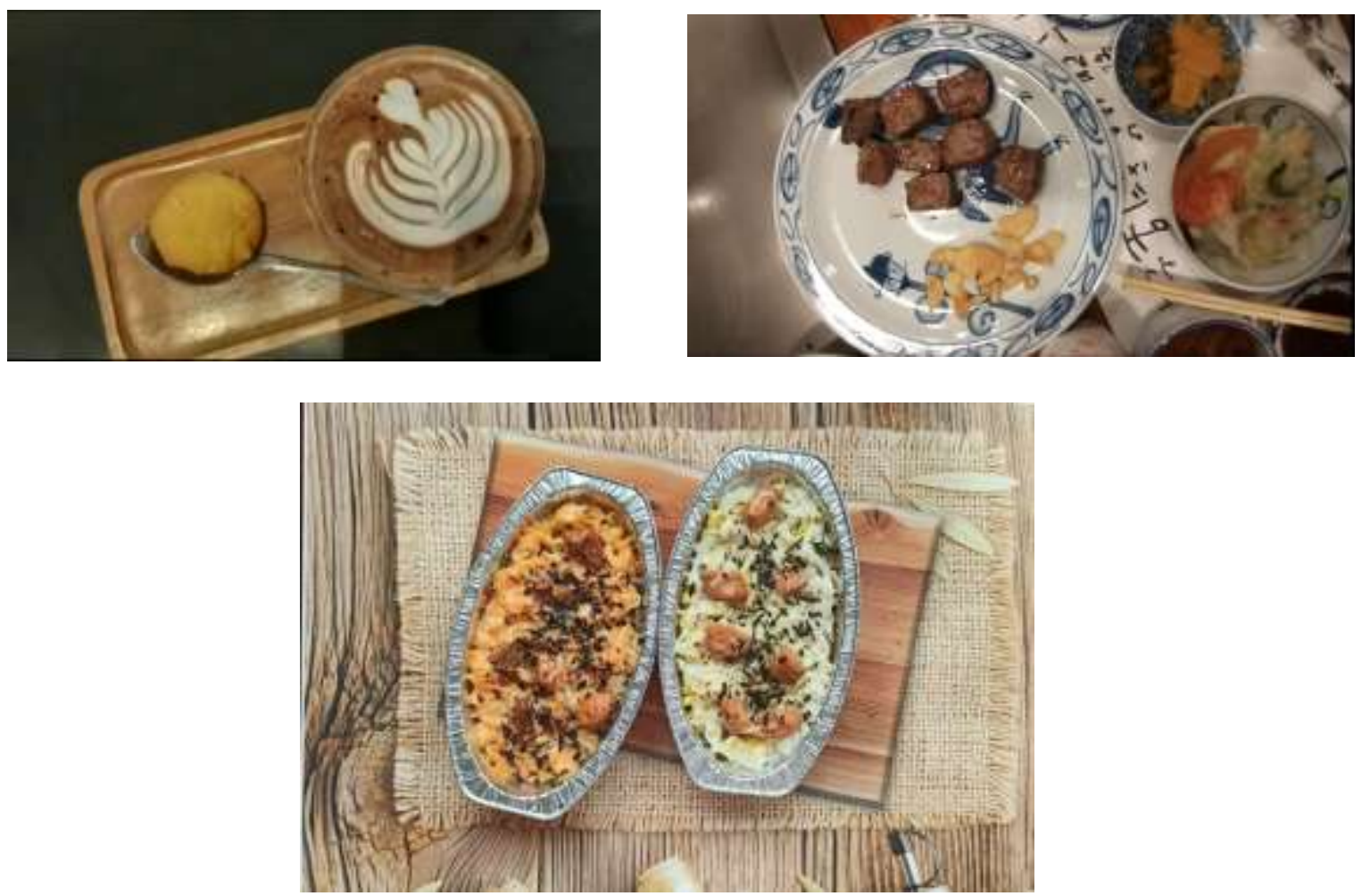

Foto 7: Karya Foto Makanan yang Dihasilkan Oleh Peserta

Pada pelatihan ini terdapat luaran Pengadian kepada Masyarakat yang dihasilkan yaitu HKI (Hak Kekayaan Intelektual) berupa hak cipta poster kegiatan, publikasi pada jurnal nasional dan publikasi pada media massa. Pelaksanaan kegiatan PkM itu juga terkorelasi dengan mata kuliah yaitu corporate and industrial photography sehingga dapat menunjang mata kuliah tersebut.

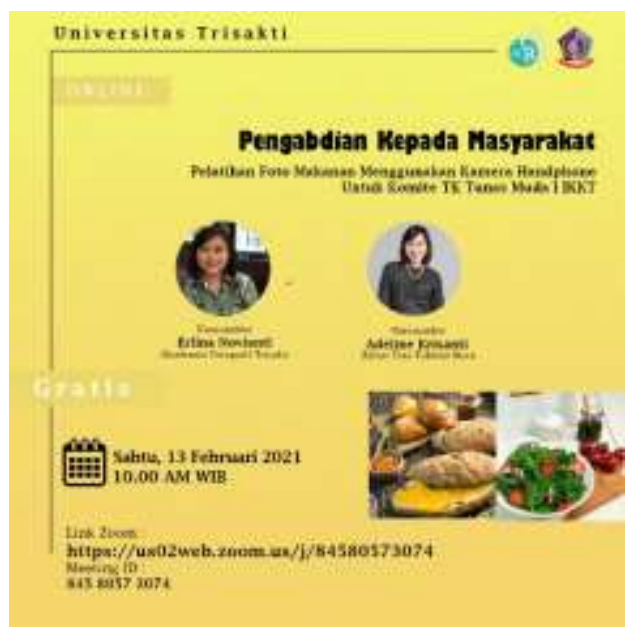

Foto 8: Luaran Hak Cipta Berupa Poster Kegiatan 


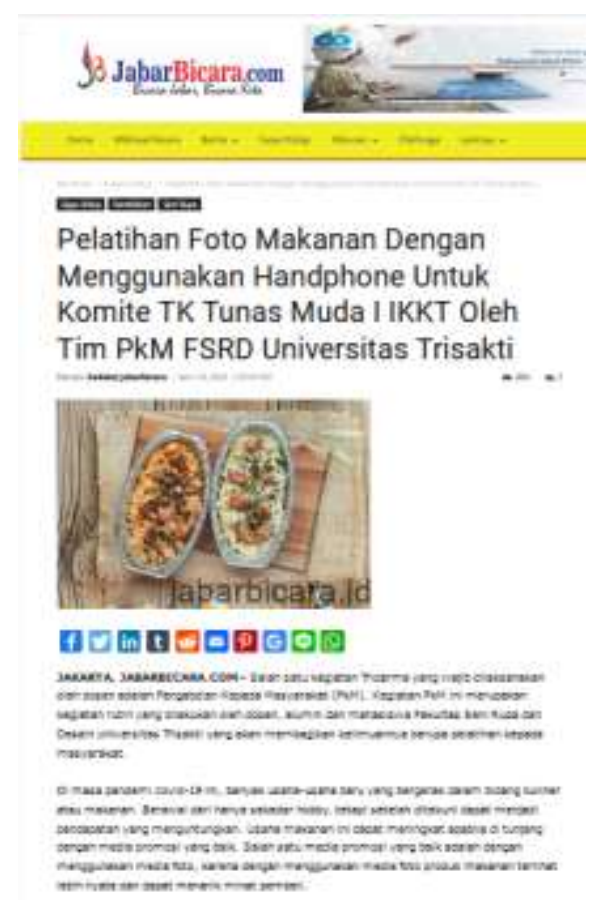

Foto 9: Publikasi di Media Massa Oline Jabar Bicara.com

\section{Simpulan}

Anggota Komite Sekolah TK Tunas Muda I IKKT merupakan salah satu wadah yang sangat positif. Selain sebagai organisasi yang mendukung sekolah juga merupakan suatu wadah yang dapat digunakan untuk meningkatkan pengetahuan dan ketrampilan. Anggota komite sekolah TK Tunas Muda I IKKT merupakan salah satu Komite Sekolah yang aktif yang selalu mengikuti dan menyelenggarakan kegiatan-kegiatan yang bermanfaat. Salah satu diantaranya adalah keikutsertaan anggota Komite Sekolah pada kegiatan pelatihan membuat foto makanan dengan menggunakan kamera handphone ini. Kegiatan pelatihan ini disambut baik oleh Komite Sekolah karena disamping dapat memberikan pengetahuan baru mengenai ilmu fotografi juga dapat meningkatkan kreatifitas dan ketrampilan anggota komite dalam menghasilkan karya foto makanan. Pada pelatihan ini selain itu hasil karya foto yang dihasilkan oleh peserta kegiatan dapat mendukung usaha kuliner yang dimiliki peserta kegiatan yaitu sebagai media promosi.

\section{Daftar Pustaka}

Paulina, A.P. (2014). Fotografi Yang Diminati Oleh Fotografer Di Indonesia. Humaniora, Vol 2, 1234-1245.

Muharini \& Listiana (2018). Belajar Fotografi Makanan Untuk Pemula. Jakarta: Trans Idea Publishing.

Tjiang Herry, (2016).7 Hari Belajar Food Fotografi, Jakarta: Elex Media Komputindo. 
Ambarsari Riana, (2014). Food Photography for Everyone, Jakarta: Elex Media Komputindo.

Hapsari Firta, (2017). Let's Do Breakfast Brunch, Jakarta.

Winengsih Ida, (2012). Pengaruh Metode Pembelajaran Demonstrasi Terhadap Kemampuan Komunikasi Matematika Siswa Pada Pokok Bahasan Kubus dan Balok, Skripsi: IAIN Syekh Nurjati Cirebon. 